\title{
Effect of Potassium and Nickel nutrition on Total Drymatter and Kernal Yield in Maize under Heat Stress
}

\author{
P. Gowthami", Y. Ashoka Rani, B. Sreekanth, Ch. Pulla Rao and Ch. Sujani Rao \\ Department of Crop Physiology, Agricultural College, Bapatla - 522101, India \\ *Corresponding author
}

\begin{tabular}{|l|}
\hline Ke y w o r d s \\
Otal drymatter, \\
$\begin{array}{l}\text { Kernal Yield, RDK } \\
\text { (Recommended } \\
\text { dose of potassium), } \\
\text { Nickel } \text { etc. }\end{array}$ \\
\hline Article Info \\
\hline $\begin{array}{l}\text { Accepted: } \\
\text { 12 June } 2019 \\
\text { Available Online: } \\
\text { 10 July } 2019\end{array}$ \\
\hline
\end{tabular}

A B S T R A C T

A field experiment was conducted during rabi 2017-18 and 2018-19 at Agricultural College Farm, Bapatla to study the 'Effect of potassium and nickel nutrition on total drymatter and yield in maize under heat stress'. The experiment was laid out in split plot design with three dates of sowing viz., December $20\left(\mathrm{M}_{1}\right)$, January $10\left(\mathrm{M}_{2}\right)$ and January 30 $\left(\mathrm{M}_{3}\right)$ as main plots and eight subplot treatments as $100 \%$ RDK (control) $\left(\mathrm{S}_{1}\right), 125 \%$ RDK $\left(\mathrm{S}_{2}\right), 1 \mathrm{~kg} \mathrm{Ni} \mathrm{ha}{ }^{-1}$ as nickel chloride $\left(\mathrm{S}_{3}\right), 2 \mathrm{~kg} \mathrm{Ni}^{-1}\left(\mathrm{~S}_{4}\right), 100 \% \mathrm{RDK}+1 \mathrm{~kg} \mathrm{Ni} \mathrm{ha}^{-1}\left(\mathrm{~S}_{5}\right)$, $100 \% \mathrm{RDK}+2 \mathrm{~kg} \mathrm{Ni} \mathrm{ha}^{-1}\left(\mathrm{~S}_{6}\right), 125 \% \mathrm{RDK}+1 \mathrm{~kg} \mathrm{Ni}^{-1}\left(\mathrm{~S}_{7}\right)$ and $125 \% \mathrm{RDK}+2 \mathrm{~kg} \mathrm{Ni} \mathrm{ha}^{-1}$ $\left(\mathrm{S}_{8}\right)$. The results revealed that total drymatter and yield in maize was influenced significantly by dates of sowing as well as nutrient treatments during both the seasons. Among the dates of sowing during both the seasons, compared to $\mathbf{M}_{1}$ the total drymatter was reduced by $8.34,6.59$ per cent in $\mathrm{M}_{2}$ and $18.38,11.86$ per cent in $\mathrm{M}_{3}$ whereas the kernal yield was reduced by $17.98,16.56$ per cent in $\mathrm{M}_{2}$ and $50.23,48.75$ per cent in $\mathrm{M}_{3}$, due to delayed sowings. Application of potassium and nickel, except nickel application without potassium $\left(\mathrm{S}_{3}\right.$ and $\left.\mathrm{S}_{4}\right)$ all other treatments enhanced the total drymatter by 6.49 to 31.51 per cent during 2017-18 and 4.89 to 24.64 per cent during 2018-19 whereas the kernel yield was increased by 6.56 to 29.98 per cent during 2017-18 and 6.18 to 28.36 per cent during 2018-19. The results revealed that application of potassium and nickel enhances the total drymatter and yield over control at all dates of sowing by contributing to a better plant growth and metabolism so that the plant can overcome the stresses undergone due to delayed sowings to some extent.

\section{Introduction}

Climate is an important factor affecting plant growth, development and productivity. Changing climate pose serious threat on crops by exposing them to various abiotic stresses as light, temperature, drought, water logging and radiation stress. Of these, temperature stress is one in which both high and low temperatures affect plant growth from sub cellular level to whole plant level, as plant metabolism includes various biochemical reactions that are sensitive to temperature. The increase in mean maximum temperature with corresponding increase in minimum temperature creates heat stress on plants. Heat stress causes multifarious and adverse effects on plant metabolism. Morphophysiological characteristics such as phenology, partitioning, shoot growth and extension were 
greatly hampered by heat stress (Hasanuzzaman et al., 2013). Heat stress during the reproductive phase had more deleterious effects on yield, particularly in cereals by reducing number of grains, grain weight and grain yield as the senescence is accelerated reducing the grain filling period.

Maize is the third most important cultivated cereal after rice and wheat. It belongs to the graminae, and designated as 'Queen of cereal' because of its high yield potential among the cereals.

Maize yield components as kernel number and weight are highly influenced by environmental conditions during anthesis and grain filling period. High temperatures reduces the number of kernals per ear by reducing number of ovules fertilized and developed into kernals as well as by increasing kernel abortion.

In coastal regions of Andhra Pradesh as maize is grown after the harvest of kharif wetland paddy. This leads to the situation that crop might face heat stress when it reaches reproductive stage.

Potassium plays an important role in plants under environmental stress conditions. It has a great role in turgor regulation, osmotic adjustment and photosynthetic carbon metabolism. Hence it offers abiotic stress resistance to plants by enhancing photosynthetic rate, plant growth and yield (Egilla et al., 2001).

Nickel, the recently recognized essential micronutrient is the active center of the enzyme urease required for nitrogen metabolism in higher plants (Yan et al. 2008). At low concentrations, it will contribute to plant growth and development by affecting the activation of many other enzymes and water relations of the plant.
Keeping in view of the above mentioned conditions, an experiment to study the effect of potassium and nickel application on total drymatter and kernel yield in maize under heat stress was taken up.

\section{Materials and Methods}

The experiment was conducted at Agricultural College Farm, Bapatla located at $15.54^{0} \mathrm{~N}$ and $80.25^{\circ} \mathrm{E}$, situated in the Agro Climatic Zone III. The experiment was laid out in split plot design with three replications, three dates of sowing viz., December $20\left(\mathrm{M}_{1}\right)$, January 10 $\left(\mathrm{M}_{2}\right)$ and January $30\left(\mathrm{M}_{3}\right)$ as main plots and eight subplot treatments as $100 \%$ RDK (control) $\left(\mathrm{S}_{1}\right), 125 \% \mathrm{RDK}\left(\mathrm{S}_{2}\right), 1 \mathrm{~kg} \mathrm{Ni}^{-1}$ as nickel chloride $\left(\mathrm{S}_{3}\right), 2 \mathrm{~kg} \mathrm{Ni} \mathrm{ha}{ }^{-1}\left(\mathrm{~S}_{4}\right), 100 \%$ $\mathrm{RDK}+1 \mathrm{~kg} \mathrm{Ni} \mathrm{ha}{ }^{-1}\left(\mathrm{~S}_{5}\right), 100 \% \mathrm{RDK}+2 \mathrm{~kg} \mathrm{Ni}$ $\mathrm{ha}^{-1}\left(\mathrm{~S}_{6}\right), 125 \% \mathrm{RDK}+1 \mathrm{~kg} \mathrm{Ni} \mathrm{ha}{ }^{-1}\left(\mathrm{~S}_{7}\right)$ and $125 \% \mathrm{RDK}+2 \mathrm{~kg} \mathrm{Ni} \mathrm{ha}^{-1}\left(\mathrm{~S}_{8}\right)$.

The total drymatter accumulation was estimated from the three plants sampled from each treatment in three replications. The plant parts were separated and dried to a constant weight in hot-air oven at $80^{\circ} \mathrm{C}$ for two days and the total dry weight was recorded and expressed in $\mathrm{g}$ plant ${ }^{-1}$.Yield was estimated from the sample collected at the time of maturity. The cobs were harvested from the five tagged plants and dried under sun. After thorough drying, shelling of cobs was done and weight of kernels was recorded and then weight was calculated per hectare.

\section{Results and Discussion}

\section{Total drymatter $\left(\right.$ g plant $\left.^{-1}\right)$}

Data on total drymatter at different days after sowing was presented in Table 1,2 and 3. The total drymatter increased gradually from 20 DAS to harvest and was influenced significantly greatly by dates of sowing and nutrient application, but their interaction was 
non significant. At 20 DAS, the highest total drymatter was recorded in timely sown crop, $\mathrm{M}_{1}$ (16.36 $\mathrm{g}$ plant $^{-1}$ during 2017-18 and 17.97 g plant ${ }^{-1}$ during 2018-19) and the lowest in the most delayed crop, $\mathrm{M}_{3}$ (11.20 $\mathrm{g} \mathrm{plant}^{-1}$ during 2017-18 and $13.46 \mathrm{~g} \mathrm{plant}^{-1}$ during 2018-19). The reduction due to the heat stress ranged from 2.23 to $5.16 \mathrm{~g} \mathrm{plant}^{-1}$ during 2017-18 and 1.94 to $4.51 \mathrm{~g} \mathrm{plant}^{-1}$ during 2018-19.

Among the subplots, all the treatments except $\mathrm{S}_{3}$ and $\mathrm{S}_{4}$, significantly increased the total drymatter compared to control and the enhancement ranged from 1.13 to $5.51 \mathrm{~g}$ plant $^{-1}$ during 2017-18 and 0.62 to $4.57 \mathrm{~g}$ plant $^{-1}$ during 2018-19. Greater total drymatter was recorded in $\mathrm{S}_{8}$ (17.71 and 19.39 g plant $^{-1}$ during 2017-18 and 2018-19 respectively) and the lower value in $S_{3}(10.23$ and $12.00 \mathrm{~g} \mathrm{plant}^{-1}$ during 2017-18 and 201819 respectively).

Greater total drymatter at 40 DAS was observed in $\mathrm{M}_{1}$ (40.05 and $40.75 \mathrm{~g} \mathrm{plant}^{-1}$ during 2017-18 and 2018-19 respectively) followed by $\mathrm{M}_{2}$ (36.28 and $38.52 \mathrm{~g} \mathrm{plant}^{-1}$ during 2017-18 and 2018-19 respectively) and $\mathrm{M}_{3}$ (32.31 and $35.39 \mathrm{~g} \mathrm{plant}^{-1}$ during 2017-18 and 2018-19 respectively). Due to delayed sowing a reduction of 3.77 to $7.74 \mathrm{~g}_{\text {plant }^{-1}}$ during $2017-18$ and 2.23 to $5.36 \mathrm{~g} \mathrm{plant}^{-1}$ during 2018-19 was observed.

With the application of potassium and nickel all the treatments except nickel alone applied treatments as $\mathrm{S}_{3}$ and $\mathrm{S}_{4}$, all the other treatments significantly enhanced the total drymatter by 1.88 to $8.98 \mathrm{~g} \mathrm{plant}^{-1}$ during 2017-18 and 1.65 to $2.84 \mathrm{~g}$ plant $^{-1}$ during 2018-19. The highest total drymatter was recorded in $\mathrm{S}_{8}$ (42.47 and $44.90 \mathrm{~g} \mathrm{plant}^{-1}$ during 2017-18 and 2018-19 respectively) and the lowest in $\mathrm{S}_{3}$ (29.85 and $31.70 \mathrm{~g} \mathrm{plant}^{-1}$ during 2017-18 and 2018-19 respectively).
At 60 DAS during both the years, greater total drymatter was recorded in $\mathrm{M}_{1}$ (94.72 and $\left.100.39 \mathrm{~g} \mathrm{plant}^{-1}\right)$ followed by $\mathrm{M}_{2}$ (86.63 and $92.93 \mathrm{~g} \mathrm{plant}^{-1}$ ) and $\mathrm{M}_{3}$ (76.28 and $83.36 \mathrm{~g}$ plant $\left.^{-1}\right)$. The reduction due to the heat stress imposed by delayed sowing ranged from 8.09 to $18.44 \mathrm{~g} \mathrm{plant}^{-1}$ and 7.46 to $17.03 \mathrm{~g} \mathrm{plant}^{-1}$ respectively.

All the treatments except $S_{3}$ and $S_{4}$, significantly enhanced the total drymatter from 3.97 to $19.17 \mathrm{~g} \mathrm{plant}^{-1}$ during 2017-18 and 3.44 to $19.09 \mathrm{~g} \mathrm{plant}^{-1}$ during 2018-19 compared to $S_{1}$. The highest total drymatter was observed in $\mathrm{S}_{8}$ (99.30 and $105.36 \mathrm{~g}$ plant $^{-}$ 1 during 2017-18 and 2018-19 respectively) and the lowest in $S_{3}$ (72.23 and 79.94 g plant $^{-1}$ during 2017-18 and 2018-19 respectively).

The highest total drymatter was recorded in $\mathrm{M}_{1}$ (190.79 and $196.96 \mathrm{~g} \mathrm{plant}^{-1}$ during 201718 and 2018-19 respectively) and the lowest in $\mathrm{M}_{3}$ (149.30 and $160.65 \mathrm{~g} \mathrm{plant}^{-1}$ during 2017-18 and 2018-19 respectively) at 80 DAS. The reduction due to delayed sowing ranged from 17.90 to $41.49 \mathrm{~g} \mathrm{plant}^{-1}$ duirng 2017-18 and 15.60 to $36.31 \mathrm{~g} \mathrm{plant}^{-1}$ duirng 2018-19.

Among the potassium and nickel treatments, except $\mathrm{S}_{3}$ and $\mathrm{S}_{4}$, all other treatments enhanced the total drymatter by 8.56 to 40.84 g plant $^{-1}$ during 2017-18 and 7.39 to $40.83 \mathrm{~g}$ plant $^{-1}$ during 2018-19 compared to $S_{1}$. Greater total drymatter was recorded by $\mathrm{S}_{8}$ (199.52 and $208.29 \mathrm{~g} \mathrm{plant}^{-1}$ during 2017-18 and 2018-19 respectively) and the least in $S_{3}$ (141.77 and $152.06 \mathrm{~g} \mathrm{plant}^{-1}$ during 2017-18 and 2018-19 respectively).

At harvest, due to delayed sowing a significant reduction of 20.50 to $45.17 \mathrm{~g}$ plant $^{-1}$ during 2017-18 and 17.29 to $31.14 \mathrm{~g}$ plant $^{-1}$ during 2018-19 was recorded. Greater total drymatter was recorded in $\mathrm{M}_{1}$ (245.69 and $262.52 \mathrm{~g} \mathrm{plant}^{-1}$ during 2017-18 and 
2018-19 respectively) followed by $\mathrm{M}_{2}$ (225.19 and $245.23 \mathrm{~g}$ plant $^{-1}$ during 2017-18 and 2018-19 respectively) whereas the least in $\mathrm{M}_{3}$ (200.52 and $231.38 \mathrm{~g}$ plant $^{-1}$ during 201718 and 2018-19 respectively).

All the treatments except $S_{3}$ and $S_{4}$ enhanced the total drymatter compared to $S_{1}$ during both the years. It ranged from 13.23 to $64.22 \mathrm{~g}$ plant $^{-1}$ and 11.20 to $56.35 \mathrm{~g}$ plant $^{-1}$ respectively. The highest value was observed in $\mathrm{S}_{8} \quad\left(268.04\right.$ and $285.08 \mathrm{~g}$ plant $^{-1}$ respectively) and the lowest in $\mathrm{S}_{3}$ (178.94 and 209.38 g plant $^{-1}$ respectively).

The reduction due to delayed sowing ranged from 8.34 to 18.38 per cent during 2017-18 and 6.59 to 11.86 per cent during 2018-19. An increment of 6.49 to 31.51 per cent during 2017-18 and 4.89 to 24.64 per cent during 2018-19 was recorded with potassium and nickel application compared to control.

Reduction in total drymatter might be due to delayed sowing resulted in delayed emergence, slow growth rate, lower photosynthetic rate and reduced translocation of assimilates due to enhanced temperatures.

Potassium promotes photosynthesis by increasing the capturing carbon and enzyme rubisco and encouraging synthesis and assimilates transport in developing plant which helps to increase the dry weight of leaves, shoot, root and total dry weight (Swetha et al., 2017).

Swetha et al. (2017) reported that application of potassium @60 kg K ${ }_{2} \mathrm{O} \mathrm{ha}{ }^{-1}$ as well as sulphur@40 kg S ha ${ }^{-1}$ increased the dry weight of leaves, shoot, root and total plant at 30,60 DAS and at harvest in maize.

Gheibi et al. (2009) observed that shoot and root dry weights were increased in maize seedlings treated with different nickel levels and supplied with urea instead of ammonium nitrate.

\section{Yield $\left(\mathrm{Kg} \mathrm{ha}^{-1}\right)$}

Yield as influenced by dates of sowing, potassium and nickel application was presented in Table 4.

A reduction in yield of 1581.16 to $4416.62 \mathrm{~kg}$ $\mathrm{ha}^{-1}$ during 2017-18 and 1482.28 to 4362.09 $\mathrm{kg} \mathrm{ha}^{-1}$ during 2018-19 respectively was observed with delay in sowing dates $\left(\mathrm{M}_{2}\right.$ and $\mathrm{M}_{3}$ ) compared to timely sown crop $\left(\mathrm{M}_{1}\right)$.

The highest yield was recorded in December 20 sown crop $\left(\mathrm{M}_{1}\right)(8792.43$ and $8948.36 \mathrm{~kg}$ $\mathrm{ha}^{-1}$ during 2017-18 and 2018-19 respectively) followed by $\mathrm{M}_{2}$ (7211.27 and $7466.08 \mathrm{~kg} \mathrm{ha}^{-1}$ during 2017-18 and 2018-19 respectively) and the lowest in the late sown crop, $\mathrm{M}_{3}$ (4375.81 and $4586.27 \mathrm{~kg} \mathrm{ha}^{-1}$ during 2017-18 and 2018-19 respectively).

During both the years, all the sub plot treatments except application of nickel without potassium $\left(S_{3}\right.$ and $\left.S_{4}\right)$ recorded a significant enhancement in yield compared to control $\left(\mathrm{S}_{1}\right)$. Maximum yield was observed in $125 \% \mathrm{~K}+2 \mathrm{~kg} \mathrm{Ni} \mathrm{ha}^{-1}\left(\mathrm{~S}_{8}\right) \quad(8072.35$ and $8256.84 \mathrm{~kg} \mathrm{ha}^{-1}$ respectively) followed by $125 \% \mathrm{~K}+1 \mathrm{~kg} \mathrm{Ni} \mathrm{ha}^{-1}\left(\mathrm{~S}_{7}\right)(7715.90$ and $7906.25 \mathrm{~kg} \mathrm{ha}^{-1}$ respectively) and minimum was recorded with $1 \mathrm{~kg} \mathrm{Ni} \mathrm{ha}{ }^{-1}\left(\mathrm{~S}_{3}\right)(5483.81$ and $5714.29 \mathrm{~kg} \mathrm{ha}^{-1}$ respectively).

Compared to $\mathrm{S}_{1}$, an increase of 407.28 to $1861.80 \mathrm{~kg} \mathrm{ha}^{-1}$ and 397.84 to $1824.36 \mathrm{~kg} \mathrm{ha}^{-1}$ respectively was recorded in all the treatments except in $\mathrm{S}_{3}$ and $\mathrm{S}_{4}$.

The reduction in yield ranged from 17.98 to 50.23 percent during 2017-18 and 16.56 to 48.75 per cent during 2018-19 respectively was observed with delayed sowings. 
Table.1 Effect of potassium and nickel nutrition on total drymatter $\left(\mathrm{g}\right.$ plant $\left.{ }^{-1}\right)$ at 20 and 40 DAS in maize under heat stress

\begin{tabular}{|c|c|c|c|c|c|c|c|c|c|c|c|c|c|c|c|c|}
\hline \multirow{3}{*}{ Treatments } & \multicolumn{8}{|c|}{20 DAS } & \multicolumn{8}{|c|}{40 DAS } \\
\hline & \multicolumn{4}{|c|}{ 2017-18 } & \multicolumn{4}{|c|}{ 2018-19 } & \multicolumn{4}{|c|}{ 2017-18 } & \multicolumn{4}{|c|}{ 2018-19 } \\
\hline & $\begin{array}{c}\mathrm{M}_{1} \\
(\operatorname{Dec} 20)\end{array}$ & $\underset{(\operatorname{Jan} 10)}{\mathrm{M}_{2}}$ & $\underset{(\operatorname{Jan} 30)}{\mathrm{M}_{3}}$ & Mean & $\begin{array}{c}\mathrm{M}_{1} \\
(\operatorname{Dec} 20)\end{array}$ & $\underset{(\operatorname{Jan} 10)}{\mathrm{M}_{2}}$ & $\underset{(\operatorname{Jan} 30)}{\mathrm{M}_{3}}$ & Mean & $\begin{array}{c}\mathbf{M}_{1} \\
(\operatorname{Dec} 20)\end{array}$ & $\begin{array}{l}\mathbf{M}_{2} \\
(\operatorname{Jan} 10)\end{array}$ & $\underset{(\operatorname{Jan} 30)}{\mathrm{M}_{3}}$ & Mean & $\begin{array}{c}\mathrm{M}_{1} \\
(\operatorname{Dec} 20)\end{array}$ & $\begin{array}{l}\mathrm{M}_{2} \\
(\operatorname{Jan} 10)\end{array}$ & $\underset{(\operatorname{Jan} 30)}{\mathrm{M}_{3}}$ & Mean \\
\hline $\begin{array}{l}S_{1}: 100 \% \\
\text { RDK }\end{array}$ & 15.28 & 12.32 & 9.01 & 12.20 & 17.05 & 14.70 & 12.72 & 14.82 & 37.33 & 33.61 & 29.54 & 33.49 & 38.10 & 36.04 & 32.32 & 35.49 \\
\hline $\begin{array}{l}\mathrm{S}_{2}: 125 \% \\
\text { RDK }\end{array}$ & 16.08 & 13.53 & 10.37 & 13.33 & 17.78 & 15.65 & 12.91 & 15.44 & 38.77 & 35.50 & 31.85 & 35.37 & 39.93 & 37.27 & 34.23 & 37.14 \\
\hline $\mathrm{S}_{3}: 1 \mathrm{~kg} \mathrm{Ni} \mathrm{ha}^{-}$ & 12.14 & 10.32 & 8.24 & 10.23 & 13.97 & 12.06 & 9.97 & 12.00 & 33.28 & 30.00 & 26.27 & 29.85 & 33.78 & 32.16 & 29.16 & 31.70 \\
\hline $\mathrm{S}_{4}: 2 \mathrm{~kg} \mathrm{Ni} \mathrm{ha}{ }^{-}$ & 12.83 & 11.30 & 8.99 & 11.04 & 15.53 & 13.67 & 10.47 & 13.22 & 34.87 & 31.50 & 28.23 & 31.53 & 35.50 & 33.91 & 30.95 & 33.46 \\
\hline$S_{5}: S_{1}+S_{3}$ & 17.14 & 14.84 & 11.53 & 14.50 & 18.20 & 16.53 & 14.17 & 16.30 & 41.07 & 37.46 & 33.51 & 37.34 & 41.49 & 39.05 & 36.69 & 39.08 \\
\hline$S_{6}: S_{1}+S_{4}$ & 18.13 & 15.79 & 12.78 & 15.57 & 19.10 & 17.45 & 14.95 & 17.17 & 43.57 & 39.06 & 34.30 & 38.97 & 44.55 & 41.98 & 39.23 & 41.92 \\
\hline$S_{7}: S_{2}+S_{3}$ & 19.11 & 16.89 & 13.83 & 16.61 & 20.37 & 18.57 & 15.72 & 18.22 & 45.02 & 40.60 & 36.39 & 40.67 & 44.81 & 42.61 & 38.76 & 42.06 \\
\hline$S_{8}: S_{2}+S_{4}$ & 20.19 & 18.08 & 14.87 & 17.71 & 21.73 & 19.66 & 16.79 & 19.39 & 46.46 & 42.53 & 38.41 & 42.47 & 47.85 & 45.11 & 41.74 & 44.90 \\
\hline Mean & 16.36 & 14.13 & 11.20 & & 17.97 & 16.03 & 13.46 & & 40.05 & 36.28 & 32.31 & & 40.75 & 38.52 & 35.39 & \\
\hline
\end{tabular}

\begin{tabular}{|c|c|c|c|c|c|c|c|c|c|c|c|c|}
\hline & \multicolumn{3}{|c|}{ 2017-18 } & \multicolumn{3}{|c|}{ 2018-19 } & \multicolumn{3}{|c|}{ 2017-18 } & \multicolumn{3}{|c|}{ 2018-19 } \\
\hline & $\begin{array}{l}\text { Main } \\
\text { plots }\end{array}$ & $\begin{array}{l}\text { Sub } \\
\text { plots }\end{array}$ & Interaction & $\begin{array}{l}\text { Main } \\
\text { plots }\end{array}$ & $\begin{array}{l}\text { Sub } \\
\text { plots }\end{array}$ & Interaction & $\begin{array}{l}\text { Main } \\
\text { plots }\end{array}$ & $\begin{array}{l}\text { Sub } \\
\text { plots }\end{array}$ & Interaction & $\begin{array}{l}\text { Main } \\
\text { plots }\end{array}$ & $\begin{array}{l}\text { Sub } \\
\text { plots }\end{array}$ & Interaction \\
\hline SEM \pm & 0.30 & 0.39 & 0.67 & 0.32 & 0.41 & 0.70 & 0.66 & 0.64 & 1.10 & 0.56 & 0.98 & 1.70 \\
\hline $\begin{array}{c}\text { CD @ } \\
0.05\end{array}$ & 1.16 & 1.11 & NS & 1.27 & 1.16 & NS & 2.59 & 1.82 & NS & 2.21 & 2.80 & NS \\
\hline CV\% & 10.44 & 8.37 & & 10.04 & 7.70 & & 8.91 & 5.30 & & 7.22 & 7.71 & \\
\hline
\end{tabular}


Table.2 Effect of potassium and nickel nutrition on total drymatter $\left(\mathrm{g}\right.$ plant $\left.{ }^{-1}\right)$ at 60 and 80 DAS in maize under heat stress

\begin{tabular}{|c|c|c|c|c|c|c|c|c|c|c|c|c|c|c|c|c|c|}
\hline \multirow{3}{*}{ Treatments } & \multicolumn{9}{|c|}{60 DAS } & \multicolumn{8}{|c|}{80 DAS } \\
\hline & \multicolumn{5}{|c|}{ 2017-18 } & \multicolumn{4}{|c|}{ 2018-19 } & \multicolumn{4}{|c|}{ 2017-18 } & \multicolumn{4}{|c|}{ 2018-19 } \\
\hline & $\begin{array}{c}\mathbf{M}_{1} \\
(\operatorname{Dec} 20)\end{array}$ & $\begin{array}{c}\mathrm{M}_{2} \\
(\operatorname{Jan} 10)\end{array}$ & $\begin{array}{c}\mathrm{M}_{3} \\
(\operatorname{Jan} 30)\end{array}$ & \multicolumn{2}{|c|}{ Mean } & \multicolumn{2}{|r|}{$\begin{array}{c}\mathbf{M}_{2} \\
(\operatorname{Jan} 10)\end{array}$} & $\begin{array}{c}\mathrm{M}_{3} \\
(\operatorname{Jan} 30)\end{array}$ & Mean & $\begin{array}{c}\mathrm{M}_{1} \\
\text { (Dec 20) }\end{array}$ & $\begin{array}{l}\mathrm{M}_{2} \\
(\operatorname{Jan} 10)\end{array}$ & $\begin{array}{c}\mathbf{M}_{3} \\
(\operatorname{Jan} 30)\end{array}$ & Mean & $\begin{array}{c}\mathbf{M}_{1} \\
(\operatorname{Dec} 20)\end{array}$ & $\begin{array}{l}\mathrm{M}_{2} \\
(\operatorname{Jan} 10)\end{array}$ & $\begin{array}{c}\mathrm{M}_{3} \\
(\operatorname{Jan} 30)\end{array}$ & Mean \\
\hline $\begin{array}{l}S_{1}: 100 \% \\
\text { RDK }\end{array}$ & 89.37 & 80.69 & 70.32 & \multicolumn{2}{|c|}{80.13} & 95.25 & 86.96 & 76.61 & 86.27 & 182.54 & 160.81 & 132.69 & 158.68 & 186.67 & 167.63 & 148.08 & 167.46 \\
\hline $\begin{array}{l}\mathrm{S}_{2}: 125 \% \\
\text { RDK }\end{array}$ & 93.17 & 85.12 & 74.01 & \multicolumn{2}{|c|}{84.10} & 98.19 & 89.96 & 80.98 & 89.71 & 188.79 & 168.62 & 144.32 & 167.24 & 194.31 & 177.03 & 153.21 & 174.85 \\
\hline $\mathrm{S}_{3}: 1 \mathrm{~kg} \mathrm{Ni} \mathrm{ha}$ & 80.24 & 73.44 & 63.01 & \multicolumn{2}{|c|}{72.23} & 89.61 & 80.46 & 69.75 & 79.94 & 156.13 & 144.07 & 125.11 & 141.77 & 164.08 & 153.18 & 138.91 & 152.06 \\
\hline $\mathrm{S}_{4}: 2 \mathrm{~kg} \mathrm{Ni} \mathrm{ha}$ & 83.81 & 77.16 & 67.25 & \multicolumn{2}{|c|}{76.07} & 91.73 & 83.18 & 72.09 & 82.34 & 167.57 & 151.11 & 131.11 & 149.93 & 172.51 & 159.88 & 142.31 & 158.24 \\
\hline$S_{5}: S_{1}+S_{3}$ & 97.45 & 88.47 & 78.43 & \multicolumn{2}{|c|}{88.12} & 102.67 & 95.63 & 84.95 & 94.42 & 195.79 & 177.48 & 153.89 & 175.72 & 202.27 & 187.66 & 161.44 & 183.79 \\
\hline$S_{6}: S_{1}+S_{4}$ & 100.86 & 92.50 & 81.53 & \multicolumn{2}{|c|}{91.63} & 105.86 & 99.53 & 90.25 & 98.55 & 204.73 & 186.11 & 160.11 & 183.65 & 211.86 & 192.55 & 171.71 & 192.04 \\
\hline $\mathbf{S}_{7}: \mathbf{S}_{2}+\mathbf{S}_{3}$ & 105.17 & 96.03 & 85.07 & \multicolumn{2}{|c|}{95.42} & 108.58 & 101.77 & 93.38 & 101.24 & 212.49 & 193.21 & 168.65 & 191.45 & 219.09 & 202.49 & 179.98 & 200.52 \\
\hline$S_{8}: S_{2}+S_{4}$ & 107.69 & 99.61 & 90.60 & \multicolumn{2}{|c|}{99.30} & 111.22 & 105.94 & 98.90 & 105. & 218.26 & 201.75 & 178.54 & 199.52 & 224.86 & 210.43 & 189.56 & 208.29 \\
\hline Mean & 94.72 & 86.63 & 76.28 & & & 100.39 & 92.93 & 83.36 & & 190.79 & 172.89 & 149.30 & & 196.96 & 181.36 & 160.65 & \\
\hline & & 2017-1 & & & & & 2018-19 & & & & 2017-1 & & & & 201 & & \\
\hline & $\begin{array}{l}\text { Main } \\
\text { plots }\end{array}$ & $\begin{array}{c}\text { Sub } \\
\text { plots }\end{array}$ & Interact & ion & & & $\begin{array}{l}\text { Sub } \\
\text { plots }\end{array}$ & Interact & ion & $\begin{array}{l}\text { Main } \\
\text { plots }\end{array}$ & $\begin{array}{c}\text { Sub } \\
\text { plots }\end{array}$ & Inter: & tion & $\begin{array}{c}\text { Main } \\
\text { plots }\end{array}$ & $\begin{array}{c}\text { Sub } \\
\text { plots }\end{array}$ & Inte & action \\
\hline SEM \pm & 2.03 & 1.90 & 3.28 & & & .91 & 1.46 & 2.52 & & 3.33 & 2.88 & 4. & & 3.68 & 3.06 & & 5.30 \\
\hline $\begin{array}{c}\text { CD@ } \\
0.05\end{array}$ & 7.98 & 5.41 & NS & & & .49 & 4.15 & NS & & 13.06 & 8.22 & $\mathrm{~N}$ & & 14.45 & 8.75 & & NS \\
\hline CV\% & 11.59 & 6.62 & & & & 0.13 & 4.73 & & & 9.53 & 5.06 & & & 10.03 & 5.12 & & \\
\hline
\end{tabular}


Table.3 Effect of potassium and nickel nutrition on total drymatter $\left(\mathrm{g} \mathrm{plant}^{-1}\right)$ at harvest in maize under heat stress

\begin{tabular}{|c|c|c|c|c|c|c|c|c|}
\hline \multirow[t]{2}{*}{ Treatments } & \multicolumn{4}{|c|}{ 2017-18 } & \multicolumn{4}{|c|}{ 2018-19 } \\
\hline & $\mathrm{M}_{1}($ Dec 20$)$ & $\mathbf{M}_{2}(\operatorname{Jan} 10)$ & $\mathrm{M}_{3}(\operatorname{Jan} 30)$ & Mean & $\mathrm{M}_{1}($ Dec 20$)$ & $\mathrm{M}_{2}(\operatorname{Jan} 10)$ & $\mathrm{M}_{3}(\operatorname{Jan} 30)$ & Mean \\
\hline $\mathrm{S}_{1}: 100 \% \mathrm{RDK}$ & 232.45 & 205.41 & 173.60 & 203.82 & 246.64 & 225.99 & 213.56 & 228.73 \\
\hline $\mathrm{S}_{2}: \mathbf{1 2 5 \%} \mathrm{RDK}$ & 239.35 & 219.33 & 192.47 & 217.05 & 257.04 & 238.52 & 224.22 & 239.93 \\
\hline$S_{3}: 1 \mathrm{~kg} \mathrm{Ni} \mathrm{ha}^{-1}$ & 191.56 & 179.78 & 165.48 & 178.94 & 224.37 & 207.89 & 195.88 & 209.38 \\
\hline $\mathrm{S}_{4}: 2 \mathrm{~kg} \mathrm{Ni} \mathrm{ha}^{-1}$ & 205.76 & 191.96 & 175.52 & 191.08 & 234.15 & 216.36 & 201.60 & 217.37 \\
\hline$S_{5}: S_{1}+S_{3}$ & 252.20 & 232.39 & 208.75 & 231.11 & 271.39 & 251.70 & 238.30 & 253.8 \\
\hline$S_{6}: S_{1}+S_{4}$ & 268.61 & 248.14 & 219.18 & 245.31 & 280.27 & 262.91 & 246.90 & 263.36 \\
\hline$S_{7}: S_{2}+S_{3}$ & 280.75 & 255.69 & 228.77 & 255.07 & 287.95 & 274.27 & 257.80 & 273.34 \\
\hline$S_{8}: S_{2}+S_{4}$ & 294.87 & 268.86 & 240.40 & 268.04 & 298.32 & 284.18 & 272.74 & 285.08 \\
\hline Mean & 245.69 & 225.19 & 200.52 & & 262.52 & 245.23 & 231.38 & \\
\hline
\end{tabular}

\begin{tabular}{|c|c|c|c|c|c|c|}
\hline & \multicolumn{3}{|c|}{ 2017-18 } & \multicolumn{3}{|c|}{ 2018-19 } \\
\hline & Main plots & Sub plots & Interaction & Main plots & Sub plots & Interaction \\
\hline SEM \pm & 3.16 & 4.60 & 7.96 & 4.24 & 3.74 & 6.48 \\
\hline CD@0.05 & 12.39 & 13.12 & NS & 16.63 & 10.67 & NS \\
\hline CV\% & 6.91 & 6.16 & & 8.42 & 4.55 & \\
\hline
\end{tabular}


Table.4 Influence of potassium and nickel nutrition on Kernal yield $\left(\mathrm{kg} \mathrm{ha}^{-1}\right)$ in maize under heat stress

\begin{tabular}{|c|c|c|c|c|c|c|c|c|}
\hline \multirow[t]{2}{*}{ Treatments } & \multicolumn{4}{|c|}{ 2017-18 } & \multicolumn{4}{|c|}{ 2018-19 } \\
\hline & $\mathrm{M}_{1}(\operatorname{Dec} 20)$ & $\mathbf{M}_{2}(\operatorname{Jan} 10)$ & $\mathbf{M}_{3}(\operatorname{Jan} 30)$ & Mean & $\mathrm{M}_{1}(\operatorname{Dec} 20)$ & $\mathbf{M}_{2}(\operatorname{Jan} 10)$ & $\mathrm{M}_{3}(\mathrm{Jan} 30)$ & Mean \\
\hline $\mathrm{S}_{1}: 100 \% \mathrm{RDK}$ & 8228.79 & 6537.01 & 3865.85 & 6210.55 & 8370.51 & 6775.48 & 4151.45 & 6432.48 \\
\hline $\mathrm{S}_{2}: \mathbf{1 2 5 \%} \mathrm{RDK}$ & 8708.49 & 6948.59 & 4196.41 & 6617.83 & 8895.46 & 7168.66 & 4426.84 & 6830.32 \\
\hline$S_{3}: 1 \mathrm{~kg} \mathrm{Ni} \mathrm{ha}^{-1}$ & 7718.86 & 5724.74 & 3007.83 & 5483.81 & 7889.15 & 6047.18 & 3206.54 & 5714.29 \\
\hline $\mathrm{S}_{4}: 2 \mathrm{~kg} \mathrm{Ni} \mathrm{ha}^{-1}$ & 7972.68 & 6145.44 & 3358.28 & 5825.47 & 8183.21 & 6426.86 & 3539.66 & 6049.91 \\
\hline$S_{5}: S_{1}+S_{3}$ & 9180.73 & 7479.52 & 4461.79 & 7040.68 & 9285.61 & 7734.05 & 4694.85 & 7238.17 \\
\hline$S_{6}: S_{1}+S_{4}$ & 9278.85 & 7868.03 & 4989.38 & 7378.76 & 9415.08 & 8107.02 & 5198.79 & 7573.63 \\
\hline$S_{7}: S_{2}+S_{3}$ & 9442.56 & 8253.48 & 5451.66 & 7715.90 & 9654.63 & 8534.89 & 5529.23 & 7906.25 \\
\hline$S_{8}: S_{2}+S_{4}$ & 9808.45 & 8733.36 & 5675.24 & 8072.35 & 9893.20 & 8934.50 & 5942.82 & 8256.84 \\
\hline Mean & 8792.43 & 7211.27 & 4375.81 & & 8948.36 & 7466.08 & 4586.27 & \\
\hline
\end{tabular}

\begin{tabular}{|c|c|c|c|c|c|c|}
\hline & \multicolumn{3}{|c|}{ 2017-18 } & \multicolumn{3}{|c|}{ 2018-19 } \\
\hline & Main plots & Sub plots & Interaction & Main plots & Sub plots & Interaction \\
\hline SEM \pm & 147.24 & 121.99 & 211.29 & 187.08 & 122.83 & 212.74 \\
\hline CD@0.05 & 578.13 & 348.16 & NS & 734.55 & 350.55 & NS \\
\hline CV\% & 10.62 & 5.39 & & 13.09 & 5.26 & \\
\hline
\end{tabular}


An enhancement in yield with all the treatments except $S_{3}$ and $S_{4}$ compared to $S_{1}$ from 6.56 to 29.98 per cent during 2017-18 and 6.18 to 28.36 per cent during 2018-19 respectively was recorded.

Reduction in yield due to delayed sowing might be due to the increased temperatures resulted in delayed emergence, decreased crop growth period, increased anthesis and silking interval leading to reduction in yield components.

The enhancement in yield with potassium and nickel application compared to control (100\% RDK) might be due to the reduction in anthesis silking interval leading to better cob filling and test weight of kernals. This indicates the role of potassium and nickel in promoting plant growth and development by overcoming the heat stress faced by late sown crops to some extent through the activation of antioxidant system, maintenance of high relative water content and photosynthetic rate.

Cheikh and Jones (1994) from the results of their experiment reported that long term exposure to high temperature severely disrupted the fresh and dry weights of kernals resulting in abortion of $97 \%$ of kernals in maize.

Ahmad and Akram, 2017 observed that application of potassium @ 100 and 200 kg $\mathrm{ha}^{-1}$ in maize crop sown under early, optimum and late sown conditions, produced maximum crop stand, cobs per plant, grains per cob, 100 grain weight and grain yield, under optimum sown condition.

Singh et al., 2011 reported that application of nickel @ 1 and $2 \mathrm{~kg} \mathrm{ha}^{-1}$ significantly increased the drymatter yield (45 DAS, straw and grain) of wheat compared to control and higher levels of nickel.

\section{References}

Ahmad, I and Akram, M. 2017. Agroeconomic evaluation of potassium application in spring maize under early and late sown conditions. Bangladesh Journal of Scientific and Industrial Research. 52(4): 295-302.

Cheikh, N and Jones, R.J. 1994. Disruption of Maize Kernel Growth and Development by Heat Stress-Role of Cytokinin/Abscisic Acid Balance. Plant Physiology. 106:45-51.

Egilla, J.N., Davies, F.T and Drew, M.C. 2001. Effect of potassium on drought resistance of Hibiscus rosasinensis cv. Leprechaun: Plant growth, leaf macro and micronutrient content and root longevity. Plant Soil. 229: 213-224.

Gheibi, M. N., Kholdebarin, B., Ghanati, F., Teimouri, S, Niroomand, $\mathrm{N}$ and Samavati, M. 2009. Urease activity in maize (Zea maize L. cv. 704) as affected by nickel and nitrogen sources. Iranian Journal of Science and Technology, Transaction A. 33(A4): 299-307.

Hasanuzzaman, M., Nahar, K., Alam, M.M., Rajib, R and Fujita, M. 2013. Physiological, biochemical, and molecular mechanisms of heat stress tolerance in plants. International Journal of Molecular Sciences. 14: 9643-9684.

Singh. R.P., Chandel, S.K.S., Yadav, P.K and Singh, S.N. 2011. Effect of $\mathrm{Ni}$ on nitrogen uptake and yield of wheat (Triticum aestivum). Indian Journal of Science and Research. 2(4): 61-63.

Swetha, P., Solanki, D., Shalini, K and Savalia, S.G. 2017. Effect of potassium and sulphur levels on yield and yield attributes of popcorn (Zea mays Var. Everta). International Journal of Current Microbiology and Applied Sciences. 6(8): 646-655. 
Yan, R., Gao, S., Yang, W., Cao, M., Wang,

phenylalanine ammonia-lyase activities $\mathrm{S}$ and Chen, F. 2008. Nickel toxicity induced antioxidant enzyme and in Jatropha curcas L. cotyledons. Plant Soil Environment. 54: 294-300.

\section{How to cite this article:}

Gowthami, P., Y. Ashoka Rani, B. Sreekanth, Ch. Pulla Rao and Sujani Rao, Ch. 2019. Effect of Potassium and Nickel nutrition on Total Drymatter and Kernal Yield in Maize under Heat Stress. Int.J.Curr.Microbiol.App.Sci. 8(07): 1640-1649.

doi: https://doi.org/10.20546/ijcmas.2019.807.195 